\title{
Synthesis of 1,2,3-Triazole Derivatives of Hydnocarpic Acid Isolated from Carpotroche brasiliensis Seed Oil and Evaluation of Antiproliferative Activity
}

\author{
Liseth S. Osorio, ${ }^{a}$ Marisa Ionta, ${ }^{b}$ Antonio J. Demuner, ${ }^{\oplus a}$ Bianca L. de Sousa, ${ }^{\circledR a}$ \\ Guilherme O. Ferraz, ${ }^{a}$ Eduardo V. V. Varejão, ${ }^{a}$ Guilherme A. Ferreira-Silva, ${ }^{b}$ \\ Eduardo J. Pilau, ${ }^{\circledR c}$ Evandro Silva ${ }^{\circledR c}$ and Marcelo H. dos Santos ${ }^{\circledR} * a$ \\ ${ }^{a}$ Departamento de Química, Universidade Federal de Viçosa, Avenida Peter Henry Rolfs, s/n, \\ Campus Universitário, 36570-900 Viçosa-MG, Brazil \\ ${ }^{b}$ Instituto de Ciências Biomédicas, Universidade Federal de Alfenas, Rua Gabriel Monteiro da Silva, \\ 700, Centro, 37130-001 Alfenas-MG, Brazil \\ ${ }^{c}$ Departamento de Química, Universidade Estadual de Maringá, Avenida Colombo, 5790, \\ Campus Universitário, 87020-900 Maringá-PR, Brazil
}

\begin{abstract}
Carpotroche brasiliensis is a tree native to Brazil, belonging to the family Flacurtiaceae, whose seeds contain a group of cyclopentenyl fatty acids: gorlic (12\%), chaulmugric (27\%), and hydnocarpic (48.7\%). These compounds are considered the main therapeutic agents in the treatment of leprosy. In the present study, a series of novel triazole compounds were obtained by conjugation between hydnocarpic acid and functionalized azides via copper(I)-catalyzed azidealkyne cycloaddition reaction (CuAAC). Hydnocarpic acid and its derivatives were tested against estrogen-positive breast carcinoma (MCF-7), hepatocellular carcinoma (HepG2), and non-small cell lung cancer (A549) cell lines. The $(R)$-(1-(pyridin-2-ylmethyl)-1H-1,2,3-triazol-4-yl)methyl11-(cyclopent-2-en-1-yl)undecanoate (8) displayed promising antiproliferative activity against A549 cells. We demonstrated that this compound selectively inhibited the viability of A549 cell cultures. Furthermore, compound $\mathbf{8}$ inhibited the clonogenic capacity of A549 cells, and this effect was associated to its ability to inhibit cell cycle progression at G1 phase. These findings indicate that $\mathbf{8}$ is a promising antitumor agent on A549 cells and support further studies to evaluate the molecular mechanisms underlying its antiproliferative activity. In addition, hydnocarpic acid should be considered as a promising chemical prototype to obtain novel antineoplastic agents.
\end{abstract}

Keywords: Carpotroche brasiliensis, cyclopentenyl fatty acids, hydnocarpic acid, triazoles, antiproliferative activity

\section{Introduction}

Cancer is a complex disease that arises from the combined effects of genetic, epigenetic, and environmental factors. $^{1,2}$ Malignant cells display selective growth, proliferative advantage, and altered stress response, favoring overall survival, vascularization, invasion, and metastasis. ${ }^{2}$

Lung cancer has been the leading cause of cancerrelated death, with around 1.6 million tumor-related deaths occurring annually worldwide. ${ }^{3}$ Non-small cell lung cancer (NSCLC) accounts for nearly $85 \%$ of all newly diagnosed cases. Unfortunately, the most patients are diagnosed at

*e-mail: marcelo_hs@yahoo.com.br late-stage disease, when surgery is no longer feasible. The standard therapy for patients with unresectable locally advanced NSCLC is the combination of cytotoxic therapy and thoracic radiation. ${ }^{4}$ In general, chemotherapy regimen is based in combined use of platinum-based compound with other cytotoxic drugs. However, a modest clinical outcome has been observed in response to multiple cytotoxic regimens used in patients with advanced stage NSCLC. Thus, it is imperative to identify new substances to improve therapeutic proposals against NSCLC.

Based on the assumption that molecules generated by the combination of pharmacophoric groups may have greater biological potential, many of such hybrid molecules, particularly heterocyclic compounds, have been produced and investigated as anticancer agents. ${ }^{4}$ 
Among the wide variety of chemical classes investigated as building blocks for the production of hybrid molecules, the triazole ring structure has been showing promising application, being capable of acting both as an essential part of the pharmacophoric group or as a linker for other molecular moieties. ${ }^{5-7}$

In the context of molecular hybridization, the click reaction, known as the copper(I)-catalyzed azide-alkyne cycloaddition reaction (CuAAC), offers an approach for the synthesis of compounds containing exclusively the 1,2,3-triazole ring. ${ }^{8}$ Triazoles gained highlight in the field of medicinal chemistry because of the stability of the triazole ring against metabolic degradation, and its ability to form hydrogen bonds, which can respectively favor the binding to biomolecules and the solubility of the compounds in biological media. ${ }^{5,6,9}$

A range of molecules presenting the 1,2,3-triazole skeleton have showed promising effects against a variety of tumor cell lines. ${ }^{10-12}$ Likewise, studies ${ }^{13-17}$ have demonstrated that many compounds derived from naturally-occurring fatty acids have shown interesting therapeutic properties, including anticancer activity against a diversity of tumor cell lines. Among them, cyclopentenyl fatty acids have exhibited antiinflammatory ${ }^{18}$ and antituberculosis effects ${ }^{19,20}$ and are considered constituents in the seed oil of the genus Hydnocarpus and Carpotroche brasiliensis (Raddi) A. Gray. In 1850, this oil was considered the main therapeutic agent against leprosy and subsequently, its use was extended to the treatment of other skin diseases. ${ }^{21-23}$

Carpotroche brasiliensis (Raddi) A. Gray is a tropical tree, native to Brazil, found in the hilly forests of the states of São Paulo, Rio de Janeiro, Minas Gerais, Espírito Santo, Bahia, and Piauí. ${ }^{21}$ The fruits contain seeds formed by dark brown oily walnuts and coated with a rigid surface bark, which have cyclopentenyl fatty acids: gorlic, chaulmugric, and hydnocarpic acids (Figure 1). ${ }^{21}$ Traditional medicine reports $^{21,24,25}$ have shown that the oil extracted from the seeds of Carpotroche brasiliensis has insecticidal, parasiticidal, antileprotic functions and is also effective in combating dandruff, lice, and herpetic manifestations.

At the best of our knowledge, there are no reports about studies on anticancer activities of cyclopentenyl fatty acids and their derivatives so far. Thus, considering that cyclopentenyl fatty acids have demonstrated other relevant biological properties, and that many 1,2,3-triazole ring skeleton has been regarded as a key structural moiety in some anticancer molecules, the present work aimed to produce a series of hydnocarpic acid derivatives bearing triazole rings and to investigate their antitumor activity.

\section{Results and Discussion}

Chromatographic fractionation of the crude organic extract obtained from the seeds of the mature fruits of Carpotroche brasiliensis yielded a considerable extract fraction consisting of a white solid. The obtained fractions were characterized by the gas chromatography technique coupled to mass spectrometry (GC-MS). The analysis showed a mixture of fatty acids, including the hydnocarpic acid (1). Because the chromatographic column separation of this mixture, using conventional silica, is difficult, silver ion chromatography was used for isolation of compound $\mathbf{1}$. This technique is used to increase the selectivity of the stationary phase and it enables separation according to the number, geometrical configuration and position of double bonds in molecules, being useful in the resolution of complex non-polar mixtures. ${ }^{26,27}$

The obtained mass spectra showed the peak of the molecular ion at $m / z 252[\mathrm{M}]^{+}$, which is consistent with the molecular mass of hydnocarpic acid (1). The base peak at $m / z 67$, characteristic of cyclopentenyl cation, and a fragment at $\mathrm{m} / \mathrm{z} 235$, consistent with the loss of the hydroxyl by the molecular ion, are also compatible with the structure of hydnocarpic acid. ${ }^{28-30}$ The ${ }^{1} \mathrm{H}$ nuclear magnetic resonance ( ${ }^{1} \mathrm{H}$ NMR) spectrum of the compound 1 showed a multiplet at the $\delta 5.68$ range, corresponding to the signal of the olefinic hydrogens of the cyclopentene ring. A multiplet
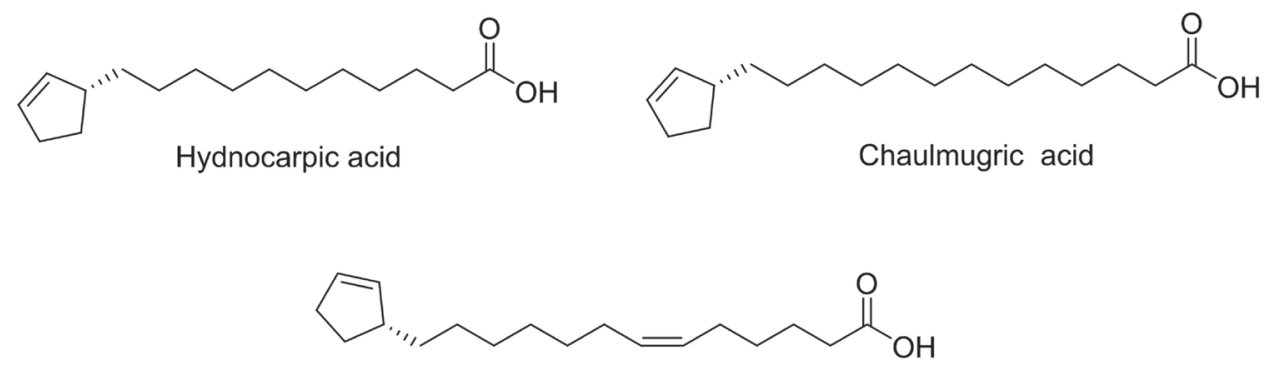

Gorlic acid

Figure 1. Cyclopentenyl fatty acids extracted from Carpotroche brasiliensis seed oil. 
at the $\delta 2.60$ range was attributed to the hydrogen of the diastereotopic carbon, and the signal at the $\delta 1.26$ range corresponds to the methylene hydrogens of the carbon chain. The chemical carbon signals were compatible with the structure of the compound in the ${ }^{13} \mathrm{C}$ NMR spectrum. The molecular formula of the hydnocarpic acid was confirmed by high resolution mass spectrometry (HRMS) analysis.

Following the chemical characterization of the hydnocarpic acid as the main metabolite isolated from the seeds, this compound was subjected to chemical modification to produce a series of derivatives presenting different substituted 1,2,3-triazole rings. The synthesis of the 1,2,3-triazoles derived from the hydnocarpic acid (1) was performed via CuAAC between functionalized azides 3a-3d, 3e, 3f and the terminal alkyne prop-2-yn-1-yl (R)-11-(cyclopent-2-en-1-yl)undecanoate (2) (Figure 2).
For this, hydnocarpic acid (1) was first propargylated to produce the alkyne 2 ( $82 \%$ yield). Concomitantly, azides 3a-3d and 3e, $\mathbf{3 f}$ were produced form the corresponding benzyl bromides or alcohols. Then, the azides were made to react with alkyne 2 to obtain the derived triazoles 4-7, $\mathbf{8}, \mathbf{9}$ as final products with yields ranging from 45 to $70 \%$. The obtained compounds were characterized by means of infrared (IR), ${ }^{1} \mathrm{H}$ and ${ }^{13} \mathrm{C}$ NMR spectroscopies, HRMS and specific rotation, $[\alpha]_{D}$. The IR spectrum showed the bands expected for the triazolic derivatives. The ${ }^{1} \mathrm{H}$ NMR spectrum of all products exhibited the signal of the olefinic proton of the triazole ring as a singlet close to $\delta 7.50$. Signals corresponding to the benzene ring hydrogens were observed at the $\delta$ 7.00-7.69 range. The ${ }^{1} \mathrm{H}$ NMR spectrum of compound $\mathbf{8}$ showed a singlet at $\delta 7.74$, which corresponds to the signal of the olefinic proton of the triazole ring, and the multiplets at the $\delta 7.18$ and 7.68 range correspond to (a)<smiles>O=C(O)CCC1CC=CC1</smiles>

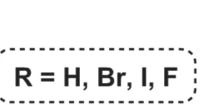<smiles></smiles>
(ii)<smiles>C#CCOC(=O)CCC1C=CCC1</smiles><smiles>[R]c1ccc(Cn2cc(COC(=O)CCC3C=C(C)CC3)nn2)cc1</smiles>
3a-3d

(b)<smiles>O=C(O)CCC1CCCC1</smiles>
1<smiles>OCc1ccccn1</smiles><smiles>CC#[C+]C</smiles><smiles>NCc1ccccn1</smiles><smiles>CC(CCC1C=CCC1)CC(=O)OCc1cn(Cc2ccccn2)nn1</smiles>
$3 e$

(c)<smiles>C#CCOC(=O)CCC1C=CCC1</smiles>
1<smiles>OCc1ccc2c(c1)OCO2</smiles><smiles>C=[V]C</smiles><smiles>N#CCCCC#N</smiles><smiles>NCc1ccc2c(c1)OCO2</smiles>
(iii)<smiles>O=C(CCC1C=CCC1)OCc1cn(Cc2ccc3c(c2)OCO3)nn1</smiles>

$3 f$

Figure 2. Synthetic steps involved in the preparation of triazole derivatives of hydnocarpic acid (a) 4-7; (b) 8; (c) 9. Reagents and conditions: (i) propargyl bromide (1.2 equiv.), $\mathrm{K}_{2} \mathrm{CO}_{3}$ (2.0 equiv.), acetone, reflux, $24 \mathrm{~h}, 82 \%$; (ii) sodium azide (2.0 equiv.), DMSO, r.t., 5 h; (iia) triethylamine (2.0 equiv.), Ms-Cl (1.5 equiv.), anhydrous $\mathrm{CH}_{2} \mathrm{Cl}_{2}$, nitrogen inlet, $-50{ }^{\circ} \mathrm{C}, 8 \mathrm{~h}$; (iii) $\mathrm{CuSO}_{4} \cdot 5 \mathrm{H}_{2} \mathrm{O}\left(0.20\right.$ equiv.), sodium ascorbate $\left(0.40\right.$ equiv.), DCM/ $\mathrm{H}_{2} \mathrm{O}(1: 1 \mathrm{v} / \mathrm{v})$, r.t., $12 \mathrm{~h}$, $45-70 \%$. 
the pyridine ring hydrogens. The chemical carbon signals were compatible with the structure of the compounds in the ${ }^{13} \mathrm{C}$ NMR spectrum. Finally, the molecular formulas of the triazolic derivatives were confirmed by HRMS analysis.

The cytotoxic activities of the triazole derivatives 4-9, together with their prototype $\mathbf{1}$, were evaluated against three different tumor cell lines estrogen-positive breast carcinoma (MCF-7), hepatocellular carcinoma (HepG2), and lung adenocarcinoma (A549). The compounds were first subjected to an initial screening by evaluating their cytotoxic profile at $50 \mu \mathrm{M}$. While the MCF-7 cell line displayed high resistance to all substances tested, HepG2 and A549 cells were responsive to compounds 8 and 9 (Figure 3a). Cell viability was reduced around 35 and $26 \%$ in HepG2 cultures treated with $\mathbf{8}$ and $\mathbf{9}$, respectively. A similar activity profile was observed for the A549 cell line, whose viability rate was reduced by approximately 43 and $14 \%$ in cultures treated with $\mathbf{8}$ and $\mathbf{9}$, respectively. Thus, the A549 cells and compound $\mathbf{8}$ were both selected for further investigations. The dose-response curves were constructed for compound $\mathbf{8}$ and its prototype $\mathbf{1}$ against the $\mathrm{A} 549$ cell line, producing their corresponding $\mathrm{IC}_{50}$ (concentration able to inhibit $50 \%$ growth) values: $63.96 \pm 3.98 \mu \mathrm{M}$ and $157.30 \pm 9.57 \mu \mathrm{M}$, respectively. Therefore, triazole derivative $\mathbf{8}$ was 2.5 -fold more effective than its prototype $\mathbf{1}$ (Figure $3 \mathrm{~b}$ ). We also included a non-tumorigenic cell line ( $\mathrm{HaCaT})$ in this study to analyze the selectivity of $\mathbf{8}$ for tumor cells. No cytotoxic activity for $\mathbf{8}$ was evidenced on $\mathrm{HaCaT}$ cells (Figure 3c), indicating a good selectivity by this compound for A549 tumor cells.

In a next step, we sought to investigate whether $\mathbf{8}$ has antiproliferative activity on A549 cells. For this, different methodological approaches were performed. We observed significant reduction in the colony formation of A549 cell cultures treated with 8 at 30 and $60 \mu \mathrm{M}$ (Figures $4 \mathrm{a}$ and $4 \mathrm{~b}$ ), indicating that 8 effectively inhibits the clonogenic capacity of these cells. This finding demonstrates a promising antitumor potential for $\mathbf{8}$ since tumor progression and metastasis processes are closely associated to the proliferative behavior of tumor cells. ${ }^{2}$

Morphological features of untreated and treated A549 cells are shown in Figure 4c. Elongated cells were observed in treated cultures after $48 \mathrm{~h}$ of treatment with $\mathbf{8}$, and cell cycle analysis showed an increased of cells in G0/G1, and decreased population in $\mathrm{S}$ and $\mathrm{G} 2 / \mathrm{M}$ phases in samples treated with $\mathbf{8}$ at $60 \mu \mathrm{M}$, compared to non-treated group (Figures $4 \mathrm{~d}$ and $4 \mathrm{e}$ ). Therefore, cell cycle arrest at the G1 phase was induced by 8 in A549 cultures treated for $48 \mathrm{~h}$. Dysregulation of the cell cycle is a key feature of tumor cells and, in that regard, targeting the cell cycle is an important approach in cancer therapy. Many proteins are involved with the regulation of G1 progression and G1/S transition, including cyclins D and E, CDK 4/6, CDK2, p21, and p16. ${ }^{31}$

(a)
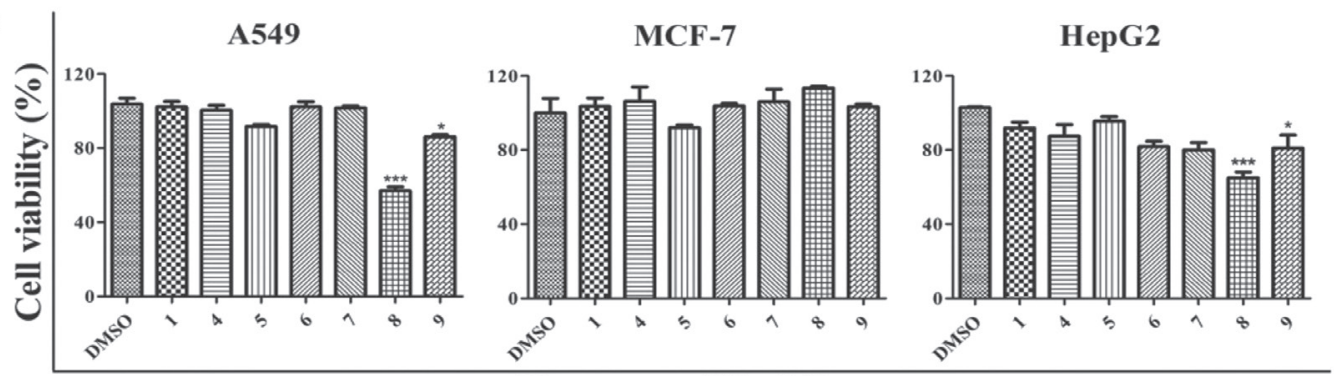

Treatment (50 $\mu \mathrm{M})$

(b)

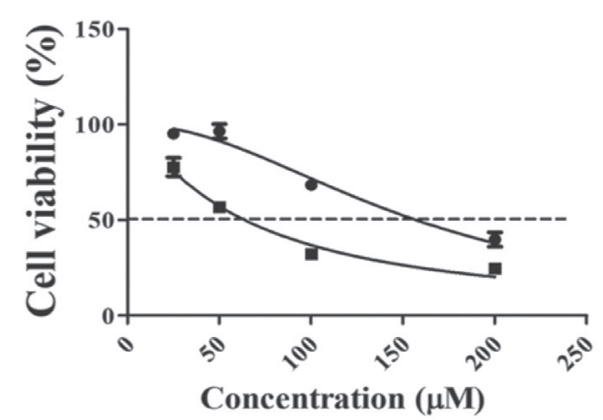

(c)

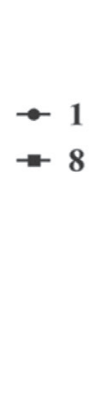

8

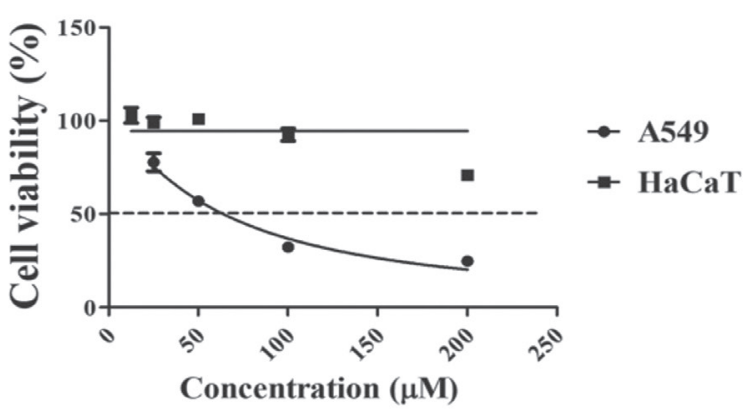

Figure 3. Cell viability determined by MTS assay after $48 \mathrm{~h}$ treatment. (a) Cell cultures were treated with triazole derivatives $\mathbf{4 - 9}$ and hydnocarpic acid $\mathbf{1}$ at $50 \mu \mathrm{M}$; (b) A549 cells were treated with $\mathbf{1}$ and $\mathbf{8}$ at different concentrations; (c) A549 and HaCaT cells were treated with 8 at different concentrations. $* p<0.05$ and $* * * p<0.001$ according to ANOVA followed by Tukey post-test. DMSO is a control group. 
(a)

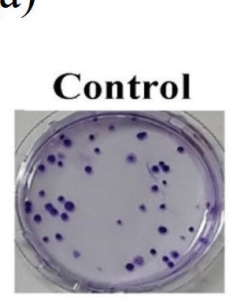

$8(\mu \mathbf{M})$

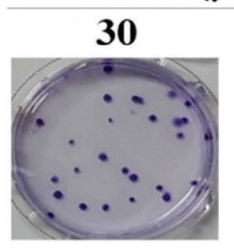

(b)

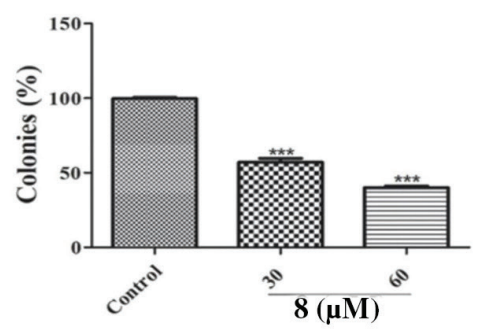

(c)
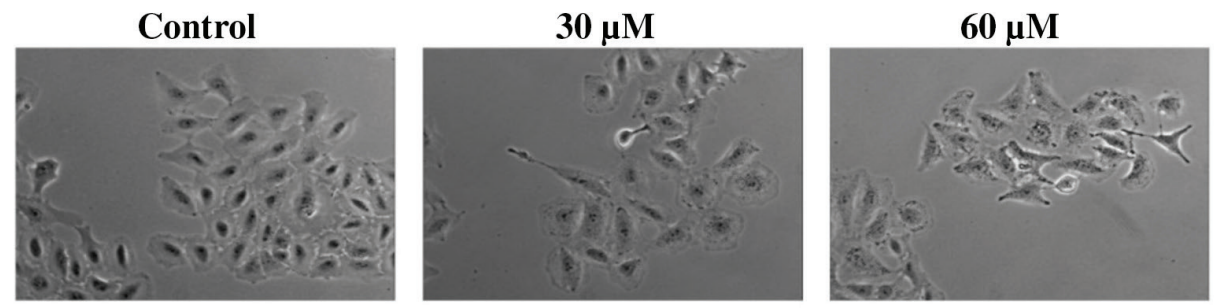

(d)
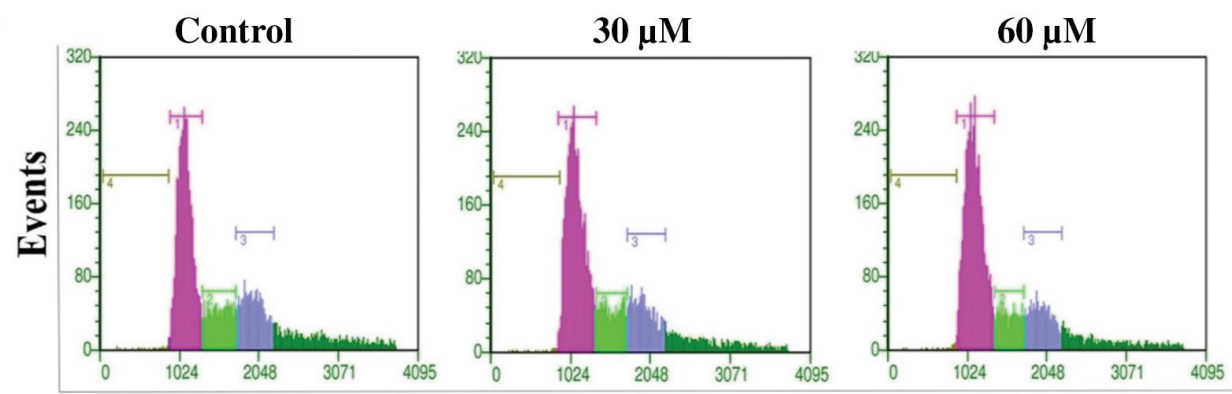

Propidium iodide

(e)

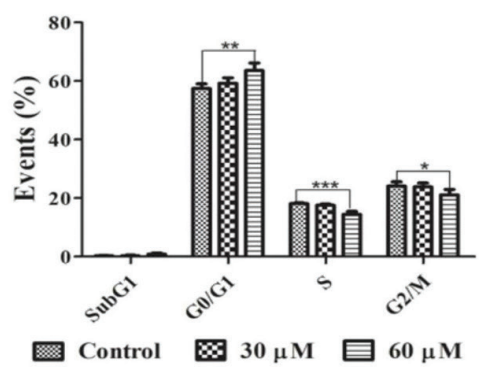

(f)

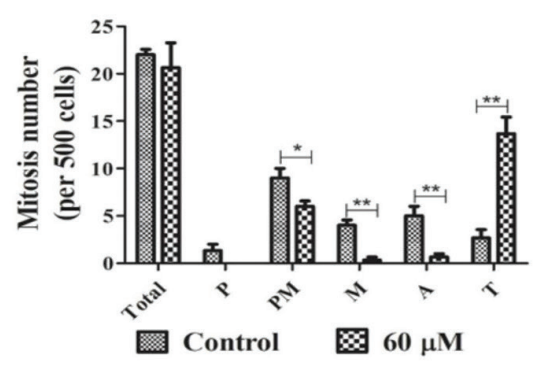

Figure 4. (a, b) Illustrative images and quantitative analysis of the clonogenic capacity assay; (c) representative images obtained by phase contrast microscopy (60× magnification) showing morphological features of A549 cells immediately before cell cycle analysis; (d) illustrative histograms showing cell populations distributed in different phases of the cell cycle after $48 \mathrm{~h}$ of treatment with $\mathbf{8}$. Brown, pink, green, and blue bars represent, respectively, sub-G1, G0/G1, S, and G2/M populations; (e) cell cycle analysis; (f) mitosis frequency determined by the counting of cells in fluorescence microscopy. $* * * p<0.001, * * p<0.01$, and $* p<0.05$ according to ANOVA followed by Tukey post-test.

Overexpression of cyclin D1 has been reported in NSCLC patients, and it seems to be associated with poor recurrencefree survival. ${ }^{32}$ The antitumor activity of many substances in NSCLC has been associated to their ability of reducing cyclin D1 expression. Hence, further studies should be performed to identify a molecular target associated with the antiproliferative activity of compound 8 on A549 cells.

Finally, we also evaluated the possible interference of 8 on mitosis progression. No significant difference was detected in the total number of mitotic cells comparing treated and control groups. Although, we detected a drastic reduction of cells in prophase, prometaphase, metaphase, and anaphase, with an increase of cells in telophase in treated cultures compared to control group. Further studies will be addressed to evaluate whether these findings are associated with the increased $\mathrm{G} 0 / \mathrm{G} 1$ population previously observed by flow cytometry. 


\section{Conclusions}

In this present study, undescribed triazole derivatives were obtained by conjugation between hydnocarpic acid and functionalized azides via the copper(I) catalyzed azidealkyne cycloaddition reaction. At the best of our knowledge, this is the first attempt to synthesize 1,2,3-triazole derivatives from hydnocarpic acid and investigate their activity against human cancer cell lines. We demonstrated that $(R)$-(1-(pyridin-2-ylmethyl)-1H-1,2,3-triazol-4-yl) methyl 11-(cyclopent-2-en-1-yl)undecanoate (8) exhibits antiproliferative activity on A549 cell lines. This effect was associated, at least in part, to its ability to inhibit cell cycle progression at the G1 phase. These findings indicate that hydnocarpic acid derivatives isolated from Carpotroche brasiliensis may be considered an important prototype for further studies in cancer therapy.

\section{Experimental}

\section{General procedure}

All commercial reagents and solvents were purchased from Sigma-Aldrich (St. Louis, MO, USA) and used as they were received. Analytical thin layer chromatography (TLC) was conducted over silica gel plates (MachereyNagel DC-Fertigfolien ALUGRAM ${ }^{\circledR}$ Xtra SIL G/UV254, Düren, Germany) and revealed under ultraviolet (UV) light $(\lambda=254 \mathrm{~nm})$ with vanillin solution. Column chromatography was performed over silica gel 60 (70-230 mesh, MachereyNagel, Düren, Germany) and flash column chromatography was employed on silica gel 60 (35-70 mesh, FlukaAnalytical, St. Gallen, Switzerland). ${ }^{1} \mathrm{H}$ NMR (300 and $400 \mathrm{MHz}$ ) and ${ }^{13} \mathrm{C}$ NMR (75 and $100 \mathrm{MHz}$ ) spectra were performed on Bruker NMR spectrometers (Billerica, Massachusetts, USA). $\mathrm{CDCl}_{3}$ was used as solvent and referenced using the solvent signal. ${ }^{1} \mathrm{H}$ NMR data presented the chemical shift assignments $(\delta)$ in ppm and $J$ values in hertz $(\mathrm{Hz})$. The numbering of the structure was used to sign the hydrogens on the spectrum and does not follow the IUPAC nomenclature. Attenuated total reflectance-Fourier transform infrared (ATR-FTIR) spectra were obtained using a Varian 660-IR (Varian, Palo Alto, CA, USA) spectrometer equipped with GladiATR scanning from 4000 to $500 \mathrm{~cm}^{-1}$. Mass spectra were obtained by electron impact ionization (EI, $70 \mathrm{eV}$ ) on Shimadzu GCMS-QP5050A (Shimadzu Europe, Duisburg, Germany) GC-MS equipment. The HRMS analysis was performed using the Impact II Bruker ESI-Q-TOF-MS (electrospray ionization-quadrupole-time of flight) mass spectrometer (Bruker Daltonics Corporation, Bremen, Germany).
The values of the rotation angle $(\alpha)$ were measured on the polarimeter ADP220, serial No. PF05050 (Bellingham+Stanley Ltd., Tunbridge Wells, Kent, UK). Sodium was used as a monochromatic light source $(\lambda=598.3 \mathrm{~nm})$ at a temperature of $24^{\circ} \mathrm{C}$ and $0.5 \mathrm{dm}$ optical path. Samples were solubilized in $2 \mathrm{~mL}$ of chloroform and the final concentration $(c)$ of the solutions was calculated

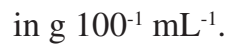

Plant material

The fruits of Carpotroche brasiliensis were acquired from the municipality of Porto Firme (2040'24" S and $\left.43^{\circ} 05^{\prime} 04^{\prime \prime} \mathrm{W}\right)$, Minas Gerais, Brazil. The Genetic Patrimony/CTA of the Carpotroche brasiliensis was registered in SisGen No. A391362.

\section{Extraction}

After removing the pericarp, the seeds of Carpotroche brasiliensis were washed with distilled water, dried at $40{ }^{\circ} \mathrm{C}$ for $48 \mathrm{~h}$ and broken to remove the nuts inside. The latter were powdered in a blender and processed by maceration for the extraction using hexane as solvent during $48 \mathrm{~h}$ ( $400 \mathrm{~g}$ of seed, $600 \mathrm{~mL}$ of hexane). The extract was filtered under vacuum and the obtained filtrate was concentrated at $45{ }^{\circ} \mathrm{C}$ using a rotatory evaporator to yield $88 \mathrm{~g}(22 \%)$ of the crude extract. The composition of the extract was investigated by GC-MS. A series of TLC analysis using different mixtures of solvents was conducted to select the mobile phase hexane:ethyl acetate:acetic acid (95:5:0.5) capable of providing the best separation of hydnocarpic acid.

\section{Fractionation of Carpotroche brasiliensis extract}

The crude organic extract (25 g) was subjected to column chromatography using silica gel (70-230 mesh) and hexane:ethyl acetate:acetic acid (95:5:0.5) as the mobile phase, resulting in 60 fractions of $25 \mathrm{~mL}$. The fractions were analyzed by TLC and grouped into two main portions, F1: 6-19 and F2: 20-60. Subsequently, the characterization was performed by GC-MS. Five grams (20\%) of mixture of fatty acids, including hydnocarpic acid, were obtained in the fraction $\mathrm{F} 2$.

\section{Hydnocarpic acid isolation}

The isolation of hydnocarpic acid was performed by silver ion chromatographic column according to Andreão et al. ${ }^{26}$ with modifications. Silica gel (35-70 mesh) impregnated with silver nitrate and hexane:ethyl acetate:acetic acid 
(95:5:0.5) mixture were used as stationary and mobile phase, respectively. Impregnation of silica, $20 \%(\mathrm{~m} / \mathrm{m})$ of $\mathrm{AgNO}_{3}$, was performed by addition of $\mathrm{AgNO}_{3}$ solution in distilled water $(10 \% \mathrm{~m} / \mathrm{v})$ to silica gel and keeping in a greenhouse for $3 \mathrm{~h}$ in the range of $105-110{ }^{\circ} \mathrm{C}$ for activation. After column compaction, $500 \mathrm{mg}$ of the fatty acid mixture (fraction 2) were incorporated into the silica impregnated with $\mathrm{AgNO}_{3}$. The column was protected from light. The elution was monitored using the GC-MS. The fractions were combined according to their composition and were obtained $60 \mathrm{mg}$ of pure hydnocarpic (12\%), whose identity was confirmed by IR, GC-MS, ${ }^{1} \mathrm{H}$ and ${ }^{13} \mathrm{C}$ NMR, and HRMS.

\section{(R)-11-(Cyclopent-2-en-1-yl)undecanoic acid (1)}

Yield: $12 \%$; white solid; $\mathrm{Rf}=0.30$ (hexane: ethyl acetate:acetic acid 95:5:0.5 v/v); $\mathrm{mp} 55.7-56.5{ }^{\circ} \mathrm{C}$; $[\alpha]_{\mathrm{D}}{ }^{24}+6.0\left(c 1.0, \mathrm{CHCl}_{3}\right)$; IR (ATR) $v / \mathrm{cm}^{-1} 3049,2917$, 2850, 1701, 1472, 1207, 1186, 1049, 912, 717; ${ }^{1} \mathrm{H}$ NMR $\left(400 \mathrm{MHz}, \mathrm{CDCl}_{3}\right) \delta 1.27-1.42$ (m, $16 \mathrm{H}, \mathrm{H} 6$ to $\left.\mathrm{H} 13\right)$, 1.60-1.67 (m, 2H, H14), 1.98-2.06 (m, 1H, H3), 2.34 (t, $4 \mathrm{H}, J 7.5 \mathrm{~Hz}, \mathrm{H} 2, \mathrm{H} 15), 2.61$ (s, 1H, H4), 5.66-5.71 (m, $2 \mathrm{H}, \mathrm{H} 1, \mathrm{H} 5) ;{ }^{13} \mathrm{C} \mathrm{NMR}\left(100 \mathrm{MHz}, \mathrm{CDCl}_{3}\right) \delta 24.84,28.12$, 29.21, 29.38, 29.57, 29.72, 29.77, 30.02, 32.12, 34.09, 36.31, 45.76, 130.12, 135.61, 179.60; MS, $\mathrm{m} / \mathrm{z}$ (\%): 252 $\left(\mathrm{M}^{+\bullet} 3\right), 235$ (2), 123 (2), 95 (4), 82 (45), 67 (100), 41 (30), 55 (25); HRMS (ESI) $\mathrm{m} / z$, calcd. for $\mathrm{C}_{16} \mathrm{H}_{28} \mathrm{O}_{2}[\mathrm{M}+\mathrm{H}]^{+}$: 275.1977, found: 275.1982 .

\section{Synthesis}

Synthesis of (R)-prop-2-ynyl-11-(cyclopent-2-enyl) undecanoate (2)

A solution of $(R)$-11-(cyclopent-2-enyl)undecanoic acid $(\mathbf{1})(0.100 \mathrm{~g}, 0.40 \mathrm{mmol})$ in acetone $(10 \mathrm{~mL})$, potassium carbonate $(0.111 \mathrm{~g}, 0.8 \mathrm{mmol})$, and 3-bromoprop-1-yne $(0.045 \mathrm{~mL}, 0.48 \mathrm{mmol})$ were sequentially transferred to a $25 \mathrm{~mL}$ round-bottomed flask and refluxed for $24 \mathrm{~h}$. The reaction was quenched with $5 \mathrm{~mL}$ of a cold water/ dichloromethane mixture $(1: 1 \mathrm{v} / \mathrm{v})$. The reaction mixture was extracted with dichloromethane $(2 \times 20 \mathrm{~mL})$ and washed with brine. The organic phase was dried over anhydrous sodium sulfate, filtered, and concentrated under reduced pressure. The yellow oil was then purified by flash silica gel column chromatography, eluted with hexane:ethyl acetate 95:5 (v/v). The structure of compound 2 was supported by the following data.

Yield: $82 \%$; yellow oil; $\mathrm{Rf}=0.69$ (hexane:ethyl acetate 9:1 v/v); IR (ATR) v / $\mathrm{cm}^{-1} 2921,2852,1729,1485,1373$, 1232, 1178, 1098, 985, 824, 720; ${ }^{1} \mathrm{H}$ NMR $(300 \mathrm{MHz}$, $\left.\mathrm{CDCl}_{3}\right) \delta 1.26$ (bs, $16 \mathrm{H}, \mathrm{H} 6$ to H13), 1.61-1.65 (m, 2H, H14), 1.95-2.07 (m, 2H, H3), 2.33 (t, 4H, J 7.5 Hz, H2,
H15), 2.45 (s, 1H, H21), 2.60 (s, 1H, H4), 4.66-4.67 (m, 2H, H19), 5.65-5.70 (m, 2H, H1, H5); ${ }^{13} \mathrm{C}$ NMR $(75 \mathrm{MHz}$, $\left.\mathrm{CDCl}_{3}\right) \delta 24.52,29.12,29.58,31.66,33.69,35.86,45.32$, $51.41,74.35,76.31,129.65,135.13,172.62$.

\section{General procedure for triazoles (4-9) one-pot synthesis}

Benzyl alcohols were converted to benzyl chlorides before formation of azides. For this, 2.0 equiv. of triethylamine and 1.5 equiv. of mesyl chloride were added to the reaction flask $(25 \mathrm{~mL})$ containing anhydrous $\mathrm{CH}_{2} \mathrm{Cl}_{2}$ in nitrogen atmosphere. The reaction was conducted for $8 \mathrm{~h}$ at $-50^{\circ} \mathrm{C}$. Benzyl bromides and benzyl chlorides (1 equiv.), 2.0 equiv. of sodium azide and $1 \mathrm{~mL}$ of dimethyl sulfoxide (DMSO) were used to obtain the organic azides. The reaction system was allowed to stir for $5 \mathrm{~h}$ at room temperature, after which 1 equiv. of alkyne $2(0.500 \mathrm{~g}, 0.17 \mathrm{mmol})$, sodium ascorbate $(0.014 \mathrm{~g}, 0.07 \mathrm{mmol})$, and $\mathrm{CuSO}_{4} .5 \mathrm{H}_{2} \mathrm{O}(0.008 \mathrm{~g}, 0.03 \mathrm{mmol})$ were added in $4 \mathrm{~mL}$ of a dichloromethane/distilled water $(1: 1 \mathrm{v} / \mathrm{v})$ solution. The reaction mixture was vigorously stirred at room temperature for $12 \mathrm{~h}$. The progress of the reaction was monitored by TLC. The mixture was then extracted with dichloromethane $(2 \times 20 \mathrm{~mL})$. After extraction, the organic phase was washed with a saturated sodium bicarbonate solution $(15 \mathrm{~mL})$. The organic phase was dried over anhydrous sodium sulfate, filtered, and concentrated under reduced pressure. The product was purified by flash silica gel column chromatography, eluted with hexane:ethyl acetate $(2: 1 \mathrm{v} / \mathrm{v})$. Structures of the synthesized compounds were supported by the following data.

(R)-(1-Benzyl-1H-1,2,3-triazol-4-yl)methyl-11-(cyclopent2-en-1-yl)undecanoate (4)

Yield: $50 \%$; white oil; $[\alpha]_{\mathrm{D}}{ }^{24}+25.53\left(c 1.175, \mathrm{CHCl}_{3}\right)$; IR (ATR) v / $\mathrm{cm}^{-1} 3064,2918,2850,1728,1548,1455$, $1165,1054,720 ;{ }^{1} \mathrm{H}$ NMR $\left(400 \mathrm{MHz}, \mathrm{CDCl}_{3}\right) \delta 1.24-1.37$ (m, 16H, H6 to H13), 1.56-1.59 (m, 2H, H14), 1.97-2.05 (m, 1H, H3), 2.29 (t, 4H, J 7.5 Hz, H2, H15), 2.60 (s, 1H, H4), 5.17 (s, 2H, H19), 5.51 (s, 2H, H25), 5.66-5.70 (m, 2H, H1, H5), 7.27-7.28 (m, 2H, H29, H31), 7.35-7.37 (m, 3H, $\mathrm{H} 27, \mathrm{H} 28, \mathrm{H} 30), 7.50$ (s, 1H, H21); ${ }^{13} \mathrm{C}$ NMR $(100 \mathrm{MHz}$, $\left.\mathrm{CDCl}_{3}\right) \delta 24.91,28.09,29.18,29.32,29.53,29.68,29.73$, 29.96, 32.08, 34.21, 36.27, 45.70, 54.32, 57.54, 123.67, $128.24,128.95,129.26,130.08,134.50,135.56,143.52$, 173.83; HRMS (ESI) $m / z$, calcd. for $\mathrm{C}_{26} \mathrm{H}_{37} \mathrm{~N}_{3} \mathrm{O}_{2}[\mathrm{M}+\mathrm{H}]^{+}$: 424.2932, found: 424.2958 .

(R)-(1-(4-Bromobenzyl)-1H-1,2,3-triazol-4-yl)methyl11-(cyclopent-2-en-1-yl)undecanoate (5)

Yield: $45 \%$; white oil; $[\alpha]_{\mathrm{D}}{ }^{24}+25.45\left(c 0.550, \mathrm{CHCl}_{3}\right)$; IR (ATR) v / $\mathrm{cm}^{-1} 3055,2916,2849,1728,1489,1468$, 
1223, 1164, 1053, 785, 486; ${ }^{1} \mathrm{H}$ NMR (300 MHz, $\mathrm{CDCl}_{3}$ ) $\delta 1.24$ (bs, 16H, H6 to H13), 1.55-1.59 (m, 2H, H14), 1.972.07 (m, 2H, H3), 2.29 (t, 4H, J 7.5 Hz, H2, H15), 2.61 (s, 1H, H4), 5.18 (s, 2H, H19), 5.47 (s, 2H, H5), 5.65-5.70 (m, 2H, H1, H5), 7.13 (d, 2H, J 8.3 Hz, H27, H31), 7.48 (s, 1H, H21), 7.51 (s, 2H, H28, H30); ${ }^{13} \mathrm{C}$ NMR (75 MHz, $\left.\mathrm{CDCl}_{3}\right) \delta 24.92,28.10,29.19,29.34,29.55,29.75,30.00$, $32.09,34.21,36.29,45.70,53.62,57.49,123.15,123.71$, 129.83, 130.10, 132.45, 133.51, 135.57, 143.74, 173.87; HRMS (ESI) $m / z$, calcd. for $\mathrm{C}_{26} \mathrm{H}_{36} \mathrm{BrN}_{3} \mathrm{O}_{2}[\mathrm{M}+\mathrm{Na}]^{+}$: 524.1871, found: 524.1883 .

(R)-(1-(4-lodobenzyl)-1H-1,2,3-triazol-4-yl)methyl11-(cyclopent-2-en-1yl)undecanoate (6)

Yield: $47 \%$; white oil; $[\alpha]_{\mathrm{D}}{ }^{24}+25.40\left(c 0.630, \mathrm{CHCl}_{3}\right)$; IR (ATR) $\mathrm{v} / \mathrm{cm}^{-1} 3049,2917,2849,1725,1469,1222$, 1163, 1057, 1009, 786, 718, 473; ${ }^{1} \mathrm{H}$ NMR (400 MHz, $\left.\mathrm{CDCl}_{3}\right) \delta$ 1.24-1.39 (m, 16H, H6 to H13), 1.56-1.59 (m, 2H, H14), 1.97-2.06 (m, 2H, H3), 2.29 (t, 4H, J 7.5 Hz, H2, H15), 2.61 (m, 1H, H4), 5.18 (s, 2H, H19), 5.46 (s, 2H, H25), 5.66-5.70 (m, 2H, H1, H5), 7.02 (d, 2H, J 9.6 Hz, H27, H31), 7.51 (s, 1H, H21), 7.70 (d, 2H, J $9.6 \mathrm{~Hz}$, $\mathrm{H} 28, \mathrm{H} 30) ;{ }^{13} \mathrm{C}$ NMR $\left(100 \mathrm{MHz}, \mathrm{CDCl}_{3}\right) \delta 24.94,28.12$, $29.21,29.35,29.56,29.73,29.77,29.99,32.11,34.23$, 36.30, 45.73, 53.74, 57.52, 94.81, 123.70, 129.99, 134.18, 135.59, 138.43, 143.77, 173.88; HRMS (ESI) $\mathrm{m} / \mathrm{z}$, calcd. for $\mathrm{C}_{26} \mathrm{H}_{36} \mathrm{IN}_{3} \mathrm{O}_{2}[\mathrm{M}+\mathrm{Na}]^{+}$: 572.1719, found: 572.1744 .

(R)-(1-(4-Fluorobenzyl)-1H-1,2,3-triazol-4-yl)methyl11-(cyclopent-2-en-1-yl)undecanoate (7)

Yield: $46 \%$; white oil; $[\alpha]_{\mathrm{D}}^{24}+24.0\left(c 0.500, \mathrm{CHCl}_{3}\right)$; IR (ATR) v / $\mathrm{cm}^{-1} 3067,2916,2849,1726,1608,1513$, 1469, 1239, 1160, 1053, 953, 789, 718; ${ }^{1} \mathrm{H}$ NMR (300 MHz, $\left.\mathrm{CDCl}_{3}\right) \delta 1.23$ (bs, $16 \mathrm{H}, \mathrm{H} 6$ to H13), 1.55-1.59 (m, 2H, H14), 1.95-2.06 (m, 2H, H3), 2.28 (t, 4H, J 7.5 Hz, H2, H15), 2.60 (s, 1H, H4), 5.17 (s, 2H, H19), 5.47 (s, 2H, H25), 5.64-5.70 (m, 2H, H1, H5), 7.02-7.08 (m, 2H, H27, H28), 7.23-7.25 (m, 2H, H30, H31), 7.50 (s, 1H, H21); ${ }^{13} \mathrm{C} \mathrm{NMR}$ $\left(75 \mathrm{MHz}, \mathrm{CDCl}_{3}\right) \delta 24.92,29.18,32.08,34.21,36.27$, $45.71,53.56,57.50,116.43$ (d, $J 21.6 \mathrm{~Hz}), 123.60,130.08$ (d, J 8.2 Hz), 130.42 (d, J 2.9 Hz), 135.56, 138.51, 143.68 , 161.37 (d, $J 248.0 \mathrm{~Hz}$ ), 173.85; HRMS (ESI) $\mathrm{m} / \mathrm{z}$, calcd. for $\mathrm{C}_{26} \mathrm{H}_{36} \mathrm{FN}_{3} \mathrm{O}_{2}[\mathrm{M}+\mathrm{Na}]^{+}:$464.2651, found: 464.2683.

(R)-(1-(Pyridin-2-ylmethyl)-1H-1,2,3-triazol-4-yl)methyl11-(cyclopent-2-en-1-yl)undecanoate (8)

Yield: $70 \%$; white oil; $[\alpha]_{\mathrm{D}}{ }^{24}+28.89\left(c 0.900, \mathrm{CHCl}_{3}\right)$; IR (ATR) $v / \mathrm{cm}^{-1} 3051,2918,2850,1730,1593,1462$, 1437, 1358, 1228, 1157, 1049, 751, 719; ${ }^{1} \mathrm{H}$ NMR (300 MHz, $\mathrm{CDCl}_{3}$ ) $\delta 1.25$ (bs, $16 \mathrm{H}, \mathrm{H} 6$ to H13), 1.57-1.64 (m, 2H, H14), 1.96-2.07 (m, 2H, H3), 2.30 (t, 4H, J 7.5 Hz,
H2, H15), 2.60 (s, 1H, H4), 5.20 (s, 2H, H19), 5.64 (s, $2 \mathrm{H}, \mathrm{H} 25)$, 5.68-5.71 (m, 2H, H1, H5), 7.18-7.24 (m, 2H, H29, H31), 7.68 (t, 1H, J 7.7 Hz, H30), 7.74 (s, 1H, H21), 8.59 (d, $1 \mathrm{H}, J 4.8 \mathrm{~Hz}, \mathrm{H} 28) ;{ }^{13} \mathrm{C} \mathrm{NMR}\left(75 \mathrm{MHz}, \mathrm{CDCl}_{3}\right)$ $\delta$ 24.57, 27.70, 28.82, 28.94, 29.15, 29.29, 29.34, 29.60, $31.69,33.86,35.89,45.34,55.39,57.20,122.18,123.19$, 123.89, 129.68, 135.18, 137.06, 143.19, 149.56, 153.98, 173.38; HRMS (ESI) $\mathrm{m} / z$, calcd. for $\mathrm{C}_{25} \mathrm{H}_{36} \mathrm{~N}_{4} \mathrm{O}_{2}[\mathrm{M}+\mathrm{H}]^{+}$: 425.2897, found: 425.2911.

(R)-(1-(Benzo[d][1,3]dioxol-5-ylmethyl)-1H-1,2,3-triazol4-yl)methyl-11-(cyclopent-2-en-1-yl)undecanoate (9)

Yield: $60 \%$; white oil; $[\alpha]_{\mathrm{D}}^{24}+18.57\left(c 1.185, \mathrm{CHCl}_{3}\right)$; IR (ATR) v / $\mathrm{cm}^{-1} 3052,2916,2849,1727,1542,1493$, 1444, 1256, 1164, 1043, 928, 775, 717; ' $\mathrm{H}$ NMR (400 MHz, $\left.\mathrm{CDCl}_{3}\right) \delta 1.23-1.38$ (m, 16H, H6 to H13), 1.56-1.59 (m, 2H, H14), 1.97-2.05 (m, 1H, H3), 2.28 (t, 4H, J 7.5 Hz, H2, H15), 2.60 (s, 1H, H4), 5.17 (bs, 2H, H19), 5.40 (bs, 2H, H25), 5.65-5.70 (m, 2H, H1, H5), 5.96 (bs, 2H, H33), 6.74 (s, 1H, H27), 6.78 (bs, 2H, H28, H31), 7.49 (s, 1H, H21); ${ }^{13} \mathrm{C} \mathrm{NMR}\left(100 \mathrm{MHz}, \mathrm{CDCl}_{3}\right) \delta 24.92,28.09,29.19,29.32$, 29.54, 29.68, 29.99, 32.08, 34.22, 36.27, 45.71, 54.17, 57.54, 101.56, 108.73, 122.16, 123.45, 128.06, 130.09, 135.57, 143.49, 148.24, 173.85; HRMS (ESI) $\mathrm{m} / \mathrm{z}$, calcd. for $\mathrm{C}_{27} \mathrm{H}_{37} \mathrm{~N}_{3} \mathrm{O}_{4}[\mathrm{M}+\mathrm{H}]^{+}$: 490.2672, found: 490.2676.

\section{Biological assays}

\section{Cell lines and culture conditions}

Human tumor cell lines used in this present study were A549 (lung adenocarcinoma), MCF-7 (estrogen-positive breast carcinoma), and HepG2 (hepatocellular carcinoma). $\mathrm{HaCaT}$ keratinocyte cell line, derived from human adult skin, was also examined. The cell cultures were maintained in Dulbecco's modified Eagle's minimum essential medium (DMEM, Sigma, St. Louis, MO, USA) supplemented with $10 \%$ fetal bovine serum (FBS, Cultilab, São Paulo, Brazil). Cells were grown in a humidified atmosphere of $95 \%$ air and $5 \% \mathrm{CO}_{2}$ at $37^{\circ} \mathrm{C}$.

\section{Cell viability assay (MTS)}

Cells were seeded in 96-well plates at a density of $1 \times 10^{4}\left(\mathrm{HepG} 2\right.$, MCF-7 and HaCaT) and $5 \times 10^{3}$ cells well $^{-1}$ (A549). The substances were used at $50 \mu \mathrm{M}$ and the experiment was conducted for $48 \mathrm{~h}$. Cell viability was assessed by MTS (3-(4.5-dimethylthiazol-2-yl)5-(3-carboxymethoxyphenyl)-2-(4-sulfophenyl)$2 \mathrm{H}$-tetrazolium) using the CellTiter $96^{\circledR}$ AQueous Non-Radioactive Cell Proliferation Assay kit (Promega Corporation, Madison, WI, USA). This method is based on the conversion of tetrazolium salt into formazan by 
the metabolically-active cells. Formazan absorbs light at $490 \mathrm{~nm}$ and the absorbance rate is directly proportional to the cell viability present in the sample. The viability rate was calculated according to equation 1 . The experiments were performed in quadruplicate and the data presented show the mean \pm standard deviation $(\mathrm{SD})$ of three independent experiments.

Cell Viability $(\%)=($ Ab sample $\times 100) /($ Ab control $)(1)$

where $\mathrm{Ab}$ is the absorbance value.

A549 and HaCaT cells were then treated for $48 \mathrm{~h}$ with different concentrations $(25,50,100$ and $200 \mu \mathrm{M})$ of substances $\mathbf{1}$ (prototype-derivative 1) and $\mathbf{8}$ to obtain dose-response curves. $\mathrm{IC}_{50}$ were determined from nonlinear regression curves using the GraphPad Prism ${ }^{\circledR 33}$ program.

Immunofluorescence and determination of cell frequency in mitosis

A549 cells were seeded into $35 \mathrm{~mm}$ diameter plates $\left(2 \times 10^{5}\right.$ cells plate $\left.^{-1}\right)$ on coverslip. Samples were treated with $8(60 \mu \mathrm{M})$ for $48 \mathrm{~h}$. The cells were fixed in 3.7\% formaldehyde in PBS (phosphate-buffered saline) for 30 min and incubated with Triton X-100 (0.5\% in PBS) for $10 \mathrm{~min}$. Subsequently, the samples were incubated with anti-tubulin (1:100, Sigma-Aldrich, St. Louis, MO, USA) at $4{ }^{\circ} \mathrm{C}$ overnight. Afterwards, secondary anti-mouse IgG-fluorescein-conjugated (1:50, Sigma, São Paulo, Brazil) was added and the sample was incubated for $2 \mathrm{~h}$ at $4{ }^{\circ} \mathrm{C}$. For filamentous actin (F-actin) analysis, samples were stained with phalloidin conjugated with tetramethylrhodamine (TRITC) (Sigma-Aldrich, St. Louis, MO, USA) for $2 \mathrm{~h}$ at room temperature. The nuclei were stained with 4',6-diamidine-2'-phenylindole dihydrochloride (DAPI, Sigma-Aldrich, St. Louis, MO, USA) and the coverslips were mounted with Vecta Shield $\left(\right.$ Vector $\left.^{\circledR}\right)$. The analysis was performed using a fluorescence microscope (Nikon) (400× magnification). The cytological preparations were used to determine the frequency of mitosis. The experiments were performed in triplicate and the data are presented as the mean $\pm \mathrm{SD}$ of two independent experiments performed in triplicate. 500 cells per sample were analyzed.

\section{Clonogenic assay}

Clonogenic assay was performed according to Franken et $a l .{ }^{34}$ Briefly, A549 cells were seeded at a low density (100 cells per $35 \mathrm{~mm}$ diameter plate) and were treated for $24 \mathrm{~h}$ with 8 at 30 and $60 \mu \mathrm{M}$. Subsequently, the cultures were recovered in a drug-free medium for 15 days. The colonies were then fixed in methanol (Sigma,
São Paulo, Brazil) for $30 \mathrm{~min}$ and stained with crystal violet. Only colonies with more than 50 cells were counted by direct visual inspection using a stereomicroscope at $20 \times$ magnification. Assays were performed in triplicate and data is presented as mean $\pm \mathrm{SD}$ of three independent experiments.

\section{Cell cycle progression analysis}

Cell cycle progression analysis was performed according to Azevedo-Barbosa et al. ${ }^{35}$ Summarily, the cells were seeded in $35 \mathrm{~mm}$ diameter Petri dishes at a density of $2 \times 10^{5}$ cells plate ${ }^{-1}$. The cells were treated with 8 at 30 and $60 \mu \mathrm{M}$ for $48 \mathrm{~h}$. After treatment, the cells were collected by enzymatic digestion (trypsin-ethylenediamine tetraacetic acid (EDTA) solution, Sigma-Aldrich Ltda., São Paulo, Brazil) and transferred to Falcon tubes. The cell precipitate was obtained through centrifugation (5 min at $1000 \mathrm{rpm}$ ). The samples were fixed with ethanol at $4{ }^{\circ} \mathrm{C}(75 \%$ in PBS) for $30 \mathrm{~min}$. After further centrifugation, cells were stained for $30 \mathrm{~min}$ in a solution containing PBS, RNAse (1.5 $\left.\mathrm{mg} \mathrm{mL}^{-1}\right)$, and propidium iodide $\left(90 \mu \mathrm{g} \mathrm{mL}^{-1}\right)($ Guava Technologies, Merck Millipore, Rockland, Massachusetts, USA). Analysis was performed using a flow cytometer (Guava Mini EasyCyte, 8HT) using the GuavaSoft $2.7^{36}$ software. Data are presented as the mean \pm SD of five independent experiments performed in duplicate.

\section{Statistical analysis}

Data were expressed as the mean $\pm \mathrm{SD}$. Analysis of variance (ANOVA) and Tukey post-test were used. The software used was GraphPad Prism ${ }^{\circledR}$ 5.0. ${ }^{33}$

\section{Supplementary Information}

Supplementary information (IR, ${ }^{1} \mathrm{H}$ and ${ }^{13} \mathrm{C}$ NMR and HRMS spectra) is available free of charge at http://jbcs.sbq.org.br as PDF file.

\section{Acknowledgments}

This work was supported by FAPEMIG (Fundação de Amparo à Pesquisa do Estado de Minas Gerais), CAPES (Coordenação de Aperfeiçoamento de Pessoal de Nível Superior, finance code 001), CNPq (Conselho Nacional de Desenvolvimento Científico e Tecnológico), and FINEP (Financiadora de Estudos e Projetos). The authors would like to thank Professor Ricardo J. Alves (Department of Pharmaceutical Products, Federal University of Minas Gerais) for the acquisition of optical activity data. 


\section{Author Contributions}

Liseth S. Osorio was responsible for the synthesis, data curation, formal analysis, investigation, methodology, writing original draft, review and editing; Marisa Ionta was responsible for the anticancer assays, data curation, formal analysis, investigation, methodology, writing original draft, review and editing; Antonio J. Demuner was responsible for the resources, review and editing; Bianca L. de Sousa was responsible for the resources, review and editing; Guilherme O. Ferraz was responsible for the synthesis, formal analysis, investigation, methodology; Eduardo V. V. Varejão was responsible for the resources, review and editing; Guilherme A. Ferreira-Silva was responsible for the anticancer assays, formal analysis, investigation, methodology; Eduardo J. Pilau was responsible for the acquisition of the HRMS, methodology, formal analysis, review and editing; Evandro Silva was responsible for the acquisition of the HRMS, methodology, formal analysis; Marcelo H. dos Santos was responsible for the data curation, formal analysis, funding acquisition, investigation, methodology, project administration, resources, supervision, writing original draft, review and editing.

\section{References}

1. Sheng, J.; Ma, N.; Wang, Y.; Ye, W. C.; Zhao, B. X.; Drug Des., Dev. Ther. 2015, 9, 1585.

2. Hanahan, D.; Weinberg, R. A.; Cell 2011, 144, 646.

3. Herbst, R. S.; Morgensztern, D.; Boshoff, C.; Nature 2018, 553, 446.

4. Chavan, P. V.; Desai, U. V.; Wadgaonkar, P. P.; Tapase, S. R.; Kodam, K. M.; Choudhari, A.; Sarkar, D.; Bioorg. Chem. 2019, 85,475 .

5. Ghiano, D. G.; Iglesia, A.; Liu, N.; Tonge, P. J.; Morbidoni, H. R.; Labadie, G. R.; Eur. J. Med. Chem. 2017, 125, 842.

6. Costa, A. V.; Moreira, L. C.; Pinto, R. T.; Alves, T. A.; Schwan, V. V.; de Queiroz, V. T.; Praça-Fontes, M. M.; Teixeira, R. R.; Morais, P. A. B.; de Jesus Júnior, W. C.; J. Braz. Chem. Soc. 2020, 31, 821 .

7. Dias, M. C. F.; Gularte, T. Q.; Teixeira, R. R.; Santos, J. A. N.; Pilau, E. J.; Mendes, T. A. O.; Demuner, A. J.; dos Santos, M. H.; J. Braz. Chem. Soc. 2019, 30, 97.

8. Kolb, H. C.; Finn, M. G.; Sharpless, K. B.; Angew. Chem., Int. Ed. 2001, 40, 2004.

9. Fu, N.; Wang, S.; Zhang, Y.; Zhang, C.; Yang, D.; Weng, L.; Zhao, B.; Wang, L.; Eur. J. Med. Chem. 2017, 136, 596.

10. Dheer, D.; Singh, V.; Shankar, R.; Bioorg. Chem. 2017, 71, 30.

11. Mareddy, J.; Suresh, N.; Kumar, C. G.; Kapavarapu, R.; Jayasree, A.; Pal, S.; Bioorg. Med. Chem. Lett. 2017, 27, 518.

12. Queiroz, T. M.; Orozco, E. V. M.; Silva, V. R.; Santos, L. S.;
Soares, M. B. P.; Bezerra, D. P.; Porto, A. L. M.; Heliyon 2019, 5, e02408.

13. Dailey, O. D.; Wang, X.; Chen, F.; Huang, G.; Anticancer Res. 2011, 31, 3165.

14. Sheela, D.; Narayanankutty, A.; Nazeem, P.; Raghavamenon, A.; Muthangaparambil, S.; Hum. Exp. Toxicol. 2019, 38, 753.

15. Mericli, F.; Becer, E.; Kabaday1, H.; Hanoglu, A.; Hanoglu, D. Y.; Yavuz, D. O.; Ozek, T.; Vatansever, S.; Pharm. Biol. 2017, 55, 1239.

16. Sanabria-Ríos, D. J.; Rivera-Torres, Y.; Rosario, J.; Ríos, C.; Gutierrez, R.; Carballeira, N. M.; Vélez, C.; Zayas, B.; ÁlvarezColón, F.; Ortiz-Soto, G.; Serrano, V.; Altieri-Rivera, J.; RíosOlivares, E.; Rodríguez, J. W.; Bioorg. Med. Chem. Lett. 2015, 25, 2174.

17. Santos, D. S.; Piovesan, L. A.; D’Oca, C. R. M.; Hack, C. R. L.; Treptow, T. G. M.; Rodrigues, M. O.; Vendramini-Costa, D. B.; Ruiz, A. L. T. G.; de Carvalho, J. E.; D’Oca, M. G. M.; Bioorg. Med. Chem. 2015, 23, 340.

18. Lima, J. A.; Oliveira, A. S.; Miranda, A. L. P.; Rezende, C. M.; Pinto, A. C.; Braz. J. Med. Biol. Res. 2005, 38, 1095.

19. Wang, J. F.; Dai, H. Q.; Wei, Y. L.; Zhu, H. J.; Yan, Y. M.; Wang, Y. H.; Long, C. L.; Zhong, H. M.; Zhang, L. X.; Cheng, Y. X.; Chem. Biodiversity 2010, 7, 2046.

20. Jacobsen, P. L.; Levy, L.; Antimicrob. Agents Chemother. 1973, $3,373$.

21. Oliveira, A. S.; Lima, J. A.; Rezende, C. M.; Pinto, A. C.; Quim. Nova 2009, 32, 139.

22. Sahoo, M. R.; Dhanabal, S. P.; Jadhav, A. N.; Reddy, V.; Muguli, G.; Babu, U. V.; Rangesh, P.; J. Ethnopharmacol. 2014, 154, 17.

23. Almahli, H.; Curr. Top. Med. Chem. 2017, 17, 2903.

24. Santos, F. S. D.; Souza, L. P. A.; Siani, A. C.; Hist. Cienc. Saude-Manguinhos 2008, 15, 29.

25. Norton, S. A.; J. Am. Acad. Dermatol. 1994, 31, 683.

26. Andreão, P. S. S.; Giacomini, R. A.; Stumbo, A. M.; Waldman, W. R.; Braz-Filho, R.; Ligiéro, C. B. P.; Miranda, P. C. M. L.; Quim. Nova 2010, 33, 212.

27. Dobson, G.; Christie, W. W.; Nikolova-Damyanova, B.; J. Chromatogr. B: Biomed. Sci. Appl. 1995, 671, 197.

28. Blaise, P.; Farines, M.; Soulier, J.; J. Am. Oil Chem. Soc. 1997, 74, 727.

29. Christie, W. W.; Brechany, E. Y.; Shukla, V. K. S.; Lipids 1989, 24,116

30. Zhang, J. Y.; Wang, H. Y.; Yu, Q. T.; Yu, X. J.; Liu, B. N.; Huang, Z. H.; J. Am. Oil Chem. Soc. 1989, 66, 242.

31. Lapenna, S.; Giordano, A.; Nat. Rev. Drug Discovery 2009, 8, 547.

32. Lee, E.; Jin, D.; Lee, B.; Kim, Y.; Han, J.; Shim, Y. M.; Kim, D. H.; BMC Cancer 2015, 15, 982.

33. GraphPad Prism ${ }^{\circledR}$, version 5.0; GraphPad Software, San Diego, CA, USA, 2007. 
34. Franken, N. A. P.; Rodermond, H. M.; Stap, J.; Haveman, J.; van Bree, C.; Nat. Protoc. 2006, 1, 2315.

35. Azevedo-Barbosa, H.; Ferreira-Silva, G. Á.; Silva, C. F.; Souza, T. B.; Dias, D. F.; Paula, A. C. C.; Ionta, M.; Carvalho, D. T.; Toxicol. In Vitro 2019, 59, 150.
36. GuavaSoft, version 2.7; EMD Millipore Corporation, Hayward, CA, USA, 2013.

Submitted: April 12, 2020

Published online: June 23, 2020 